\title{
Traces of Transport at the Vienna Hofburg Roof Constructions
}

\author{
Elisabeth Wächter | ORCID 0000-0002-3005-9033 \\ University of Natural Resources and Life Sciences, вокU, Vienna, Institute \\ of Wood Technology and Renewable Resources, Uft Tulln, Konrad Lorenz \\ Strasse 24, 3430 Tulln, Austria \\ Corresponding author, e-mail: elisabeth.waechter@boku.ac.at
}

\author{
Michael Grabner | ORCID 0000-0002-5220-721X \\ University of Natural Resources and Life Sciences, вокU, Vienna, Institute \\ of Wood Technology and Renewable Resources, Uft Tulln, Konrad Lorenz \\ Strasse 24, 3430 Tulln, Austria \\ michael.grabner@boku.ac.at
}

\begin{abstract}
The Vienna Hofburg is a large complex of buildings of unique historic importance with historical wooden constructions from the 13 th to the 20 th century. Within its wooden roof constructions, rafting wedges were found, which proves that the timber used did not originate in the surroundings of Vienna but had to be transported to the city. An ascertainment of these residual traces in eleven wings of the Hofburg building was made; five different types (within two main groups) of rafting wedges and withies (softened twigs that can be used like short ropes to tie trunks together) were defined: (1) simple flat wedges, driven into the fresh wood; (2) round or squared wedges, with or without withies driven into bored wholes. It was not possible to trace back the origin of the construction timber by means of that typology. However, the combination of dendroprovenancing and historic records found in archives led to first results.
\end{abstract}

\section{Keywords}

wood utilization - wood supply - transport of wood - dendrochronology dendroprovenancing 
The Vienna Hofburg is the biggest secular complex of buildings in Europe. The historic site was the domicile of the Austrian leadership for over eight centuries, and thus, it was a center of European politics. Awareness of the value of the existing building structures of the emperors is crucial for understanding the appearance and the architectural importance of the Vienna Hofburg today (Buchinger 2003, 384-385). The extraordinary size, continuity of construction, age, and political importance of this building forms a perfect base for research, as there are various sources of background information available. Numerous annexes were successively added to the core part of the castle, which dates to the second half of the 13th century. Thus, a huge amount of construction timber was used over time to build the various parts of the building, especially the roof and ceiling constructions.

During the dendrochronological sampling, rafting wedges were located in each roof construction of the various parts of the Hofburg. These traces of transport demonstrate that the high demand for wood in Vienna exceeded the supply from the surrounding forests in those times. For long distance, timber transport rafts were built. The origin of the wood was most likely along the River Danube itself or around its tributaries (Neweklowsky 1952, 541-624; Neweklowsky 1959, 131-138; Koller 1954, 16; Wiesenhofer and Wiesenhofer 2015, 4).

Different raft assembling techniques addressed differing rafting conditions of the respective rivers. In rough mountainous terrains, rivers rafts had to be built flexibly so that single logs were free to move, thereby limiting the risk of damaging the rafts. Conditions on bigger, calmer rivers required less complex connections; the use of a withy was avoided as much as possible (Sazenhofen 1980, 21, 30; Gayer 1894, 372). Varying local traditions also influenced raft assembling techniques. These differences can sometimes be used to assign rafts to areas of origin.

The main aim of this study was to get a better understanding of the wood supply of Vienna by analyzing the traces of transport, rafting wedges, and withies. This should lead to a typology of raft construction systems for future use as a provenancing tool, as different raft types at the various tributaries of the Danube are described in literature (Neweklowsky 1952, 604; Sazenhofen 1980, 73). 
Accessible roof constructions of eleven wings of the Hofburg were analyzed. The beams were surveyed to find rafting wedges, and their types and sizes were determined. Samples were taken to determine the wood species of both wedges and withies.

Different kinds of rafting wedges and withies were found in the roof constructions of the Hofburg. During the investigation, five different types of connector systems were classified. In the simplest case, there was just one flat wedge hammered into the fresh timber (type 1: flat wedge, see Fig. 1.4 and Fig. 2.1). In all other cases, a hole was drilled first and then either a square or a round wedge with or without a withy was applied (type 2: round wedge, Figure 1.3; type 3: round wedge with withy, Fig. 1.1; type 4: square wedge with withy, Figs 1.2 and 2.3; type 5: square wedge, Fig. 2.2).
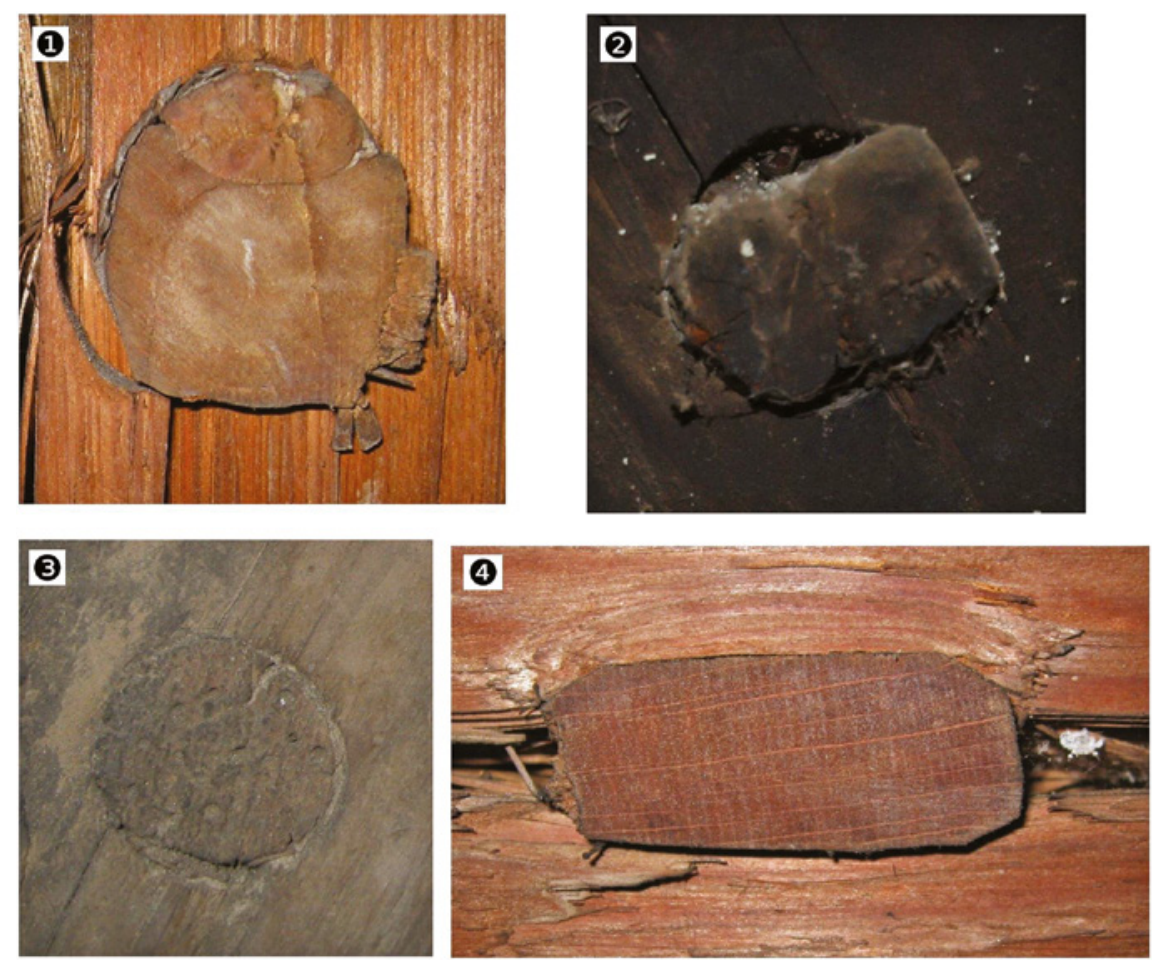

FIGURE 1 Types of rafting wedges found in the Vienna Hofburg: (1), round wedge with withy type $3 ;(2)$, square wedge with withy, type 4 ; (3), round wedge without withy, type $2 ;(4)$, flat wedge always without withy, type 1. 

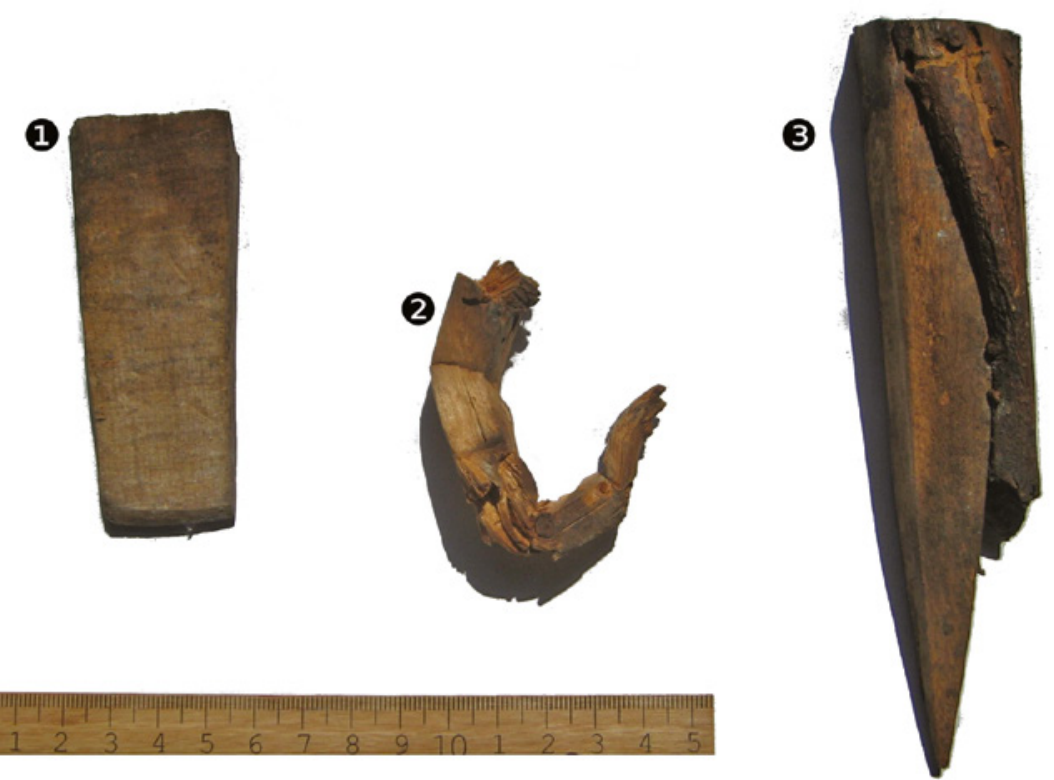

FIGURE 2 Types of rafting wedges found in the Vienna Hofburg: (1), flat wedges (type 1) made from beech (Fagus sylvatica); (2), square wedge (type 5) made from poplar or willow (Populus or Salix); (3), square wedge made from beech (Fagus sylvatica) with withy made from a spruce branch (Picea abies) (type 4).

Wood species of the rafting wedges and withies were determined either by macroscopic identification or by taking freehand microsections as described by Grosser $\left(2003,5^{\circ}\right)$ or Schweingruber $(1990,208)$ with subsequent microscopic wood species identification. Because of the small dimensions of the samples, two softwood species of spruce (Picea abies) and fir (Abies alba) as well as two hardwood species poplar (Populus spp.) and willow (Salix spp.) were not differentiated.

Borehole diameters were measured by the help of scales with a resolution of $1 \mathrm{~mm}$ to receive additional information for the system typology.

\section{Results and Discussion}

Within all roof constructions of these eleven wings, 487 rafting wedges were found and investigated. 


\begin{tabular}{|c|c|c|c|c|c|c|c|}
\hline Wings of the Hofburg & $\begin{array}{l}\text { Type 1, flat } \\
\text { wedge }\end{array}$ & $\begin{array}{l}\text { Type 2, } \\
\text { round } \\
\text { wedge }\end{array}$ & $\begin{array}{l}\text { Type } 3 \text {, } \\
\text { round } \\
\text { wedge } \\
\text { with } \\
\text { withy }\end{array}$ & $\begin{array}{l}\text { Type 4, } \\
\text { square } \\
\text { wedge } \\
\text { with } \\
\text { withy }\end{array}$ & $\begin{array}{l}\text { Type 5, } \\
\text { square } \\
\text { wedge }\end{array}$ & $\begin{array}{l}\text { Only } \\
\text { borehole }\end{array}$ & Total \\
\hline Amalienburg & 26 & 18 & 26 & 3 & 2 & 3 & 78 \\
\hline Augustinerkirche & 83 & 6 & 14 & 3 & 1 & 12 & 119 \\
\hline Hofburgkapelle & 1 & 2 & 7 & 1 & 2 & 5 & 18 \\
\hline Kindertrakt & 5 & - & - & - & - & - & 5 \\
\hline Leopldinischer Trakt & 9 & 3 & 7 & - & 4 & 1 & 24 \\
\hline Nationalbibliothek & 3 & - & 4 & 17 & - & 5 & 29 \\
\hline Reichskanzleitrakt & 4 & 3 & 11 & 4 & 1 & - & 23 \\
\hline Schweizertrakt & 34 & - & 5 & 2 & - & 1 & 42 \\
\hline Stallburg & 32 & 11 & 3 & 6 & 1 & 1 & 54 \\
\hline Winterreitschule & 10 & 2 & 8 & 26 & 3 & 6 & 55 \\
\hline Zeremoniensaal & 22 & - & 4 & 10 & - & 4 & 40 \\
\hline Total & 229 & 45 & 89 & 72 & 14 & 38 & 487 \\
\hline
\end{tabular}

\subsection{Type}

As a result of the determinations aforementioned, five types of connector systems were defined. The evaluation shows that there were almost as many wedges without a borehole (229 pieces, type 1 , Table 1 ) as wedges in the group with borehole (258 pieces, types $2-5$ ) in the various roof constructions of the Vienna Hofburg. $73 \%$ of the wedges with a borehole contained a withy $(161$ pieces, types 3 and 4 ).

\subsection{Size}

The width of the wedges of type 1 was measured in a range from 15 to $60 \mathrm{~mm}$. Figure 3 shows the distribution of the widths in the different wings of the Hofburg. It is quite homogeneous among the wings, and therefore, it does not make a further subdivision of the "type 1" connector system necessary.

From type 2 to type 5 connector systems, the diameter of the drilled borehole on the beams was measured. The hole was not always drilled perpendicular to the surface, which leads to an ellipse-shaped opening on the surface. By measuring the smallest distance, the real diameter of the borehole could be 


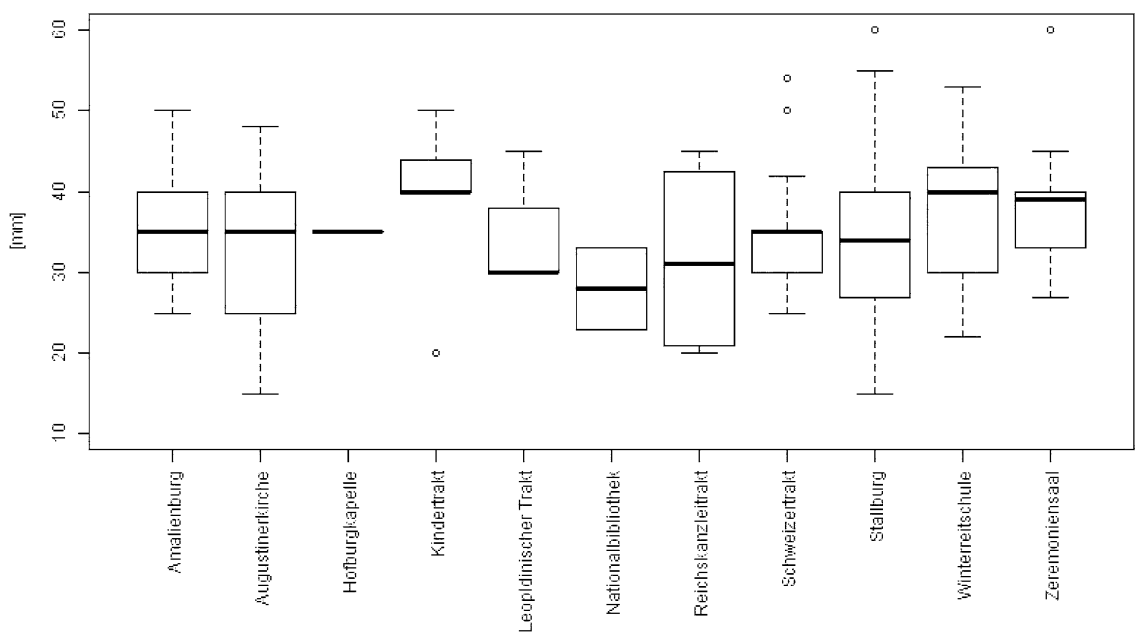

FIGURE 3 Width of the flat wedge (type 1) in the different parts of the Hofburg.

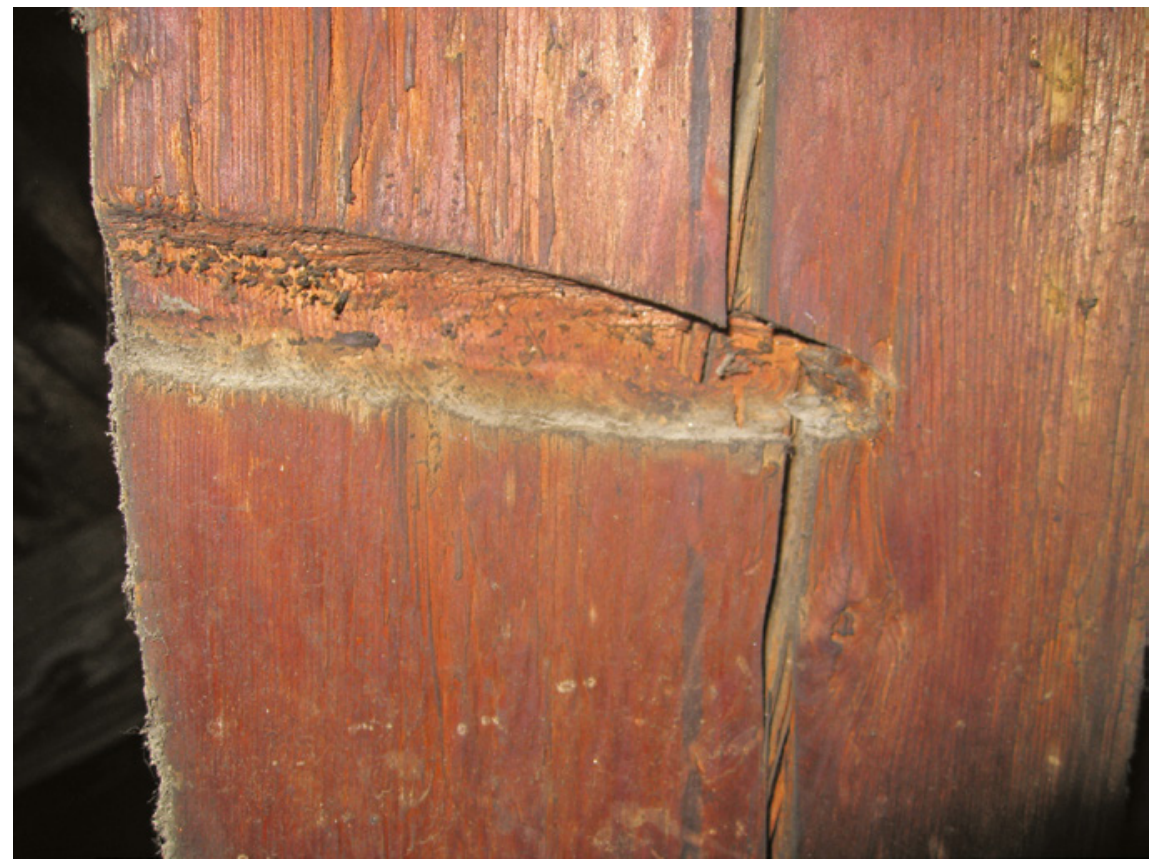

FIGURE 4 Profile of a borehole in a roof construction beam in the Hofburg.

determined. In the entire building, diameters ranged between 13 and $45 \mathrm{~mm}$. It is possible that the measured diameter describes the cone end of the drilling tool used (see Fig. 4). 


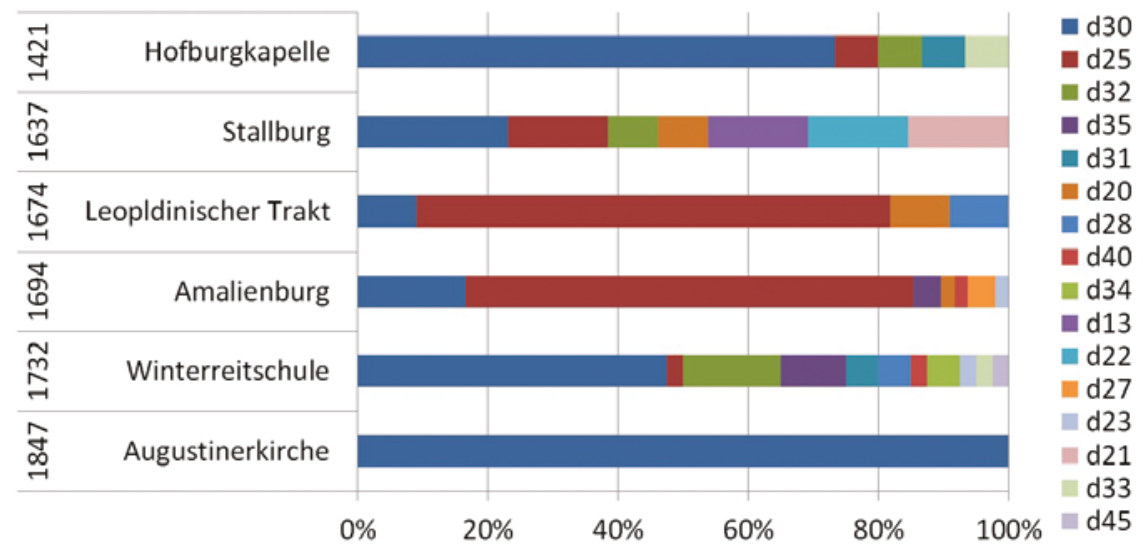

FIGURE 5 Compiled diameters $(\mathrm{mm})$ of the drilled boreholes in six parts of the Hofburg with homogeneous building phases (see the end date on the left side). The diameter in the legend is given in order of the number of counts.

Faced with a potential inaccuracy of the measurement, as aforementioned, the result of the analysis is remarkable. The most frequently measured diameters were $30 \mathrm{~mm}$ (with 59 counts in total) and $25 \mathrm{~mm}$ (with 48 counts in total) followed by the size of $35 \mathrm{~mm}$ with 11 measurements in total. Many other sizes appear in smaller number.

In Fig. 5, six parts of the Hofburg with homogenous dated constructions (meaning a single building phase at a time) show partly homogenous diameters. Although there is a wide variability, the main diameters emerge as 30 , 25, 32, and $35 \mathrm{~mm}$. In the "Leopoldinischer-Trakt" and the "Amalienburg," both built in the end of the 17 th century, clearly a diameter of $25 \mathrm{~mm}$ is dominating, while in the "Augustinerkirche" and "Hofburgkapelle" mainly boreholes of a diameter of $30 \mathrm{~mm}$ were found.

\subsection{Wood Species of Rafting Wedges}

When separating the two main groups of rafting wedges (wedges without a borehole, type 1 ; and wedges with a borehole, types 2 to 5 ) into wood species, it can be seen that almost all the flat wedges without boreholes were made out of beech (Fagus sylvatica), whereas different kind of wood species were used for the wedges with boreholes (see figure 6). For wedges with a borehole, spruce or fir (Picea abies or Abies alba), poplar or willow (Populus spp. or Salix spp.), and beech (Fagus sylvatica) were almost used in equal measure. Additionally, hazel (Corylus avellana) and birch (Betula pendula) were identified frequently. Larch (Larix decidua), pine (Pinus sylvestris), and oak (Quercus spp.) were used sporadically. The mechanical requirements for the material of flat wedges are 

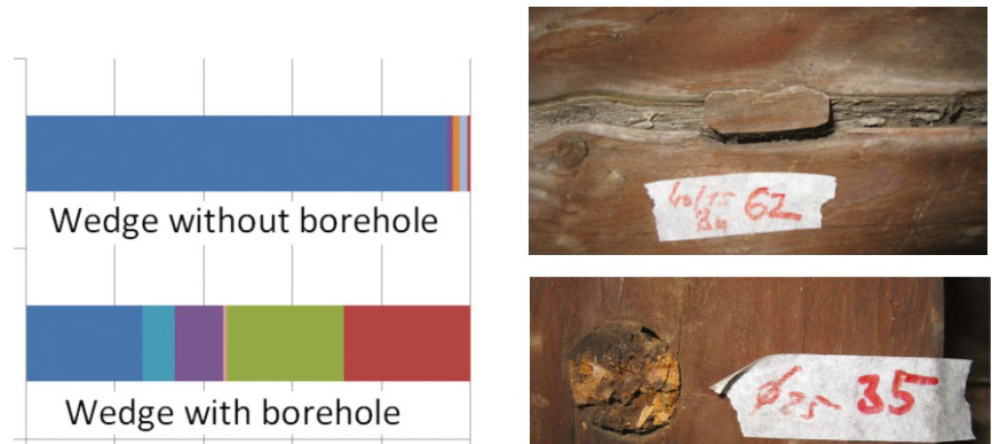

$\begin{array}{llllll}0 \% & 20 \% & 40 \% & 60 \% & 80 \% & 100 \%\end{array}$

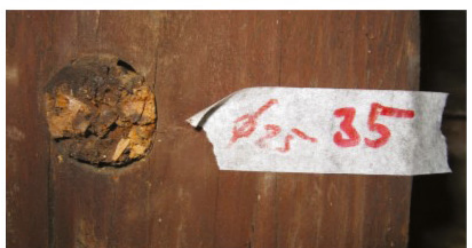

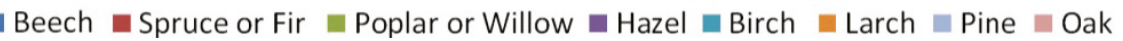

FIGURE 6 Used wood species separated in wedges with and without borehole.

different than those where a hole is drilled beforehand. This can explain why beech was used predominantly.

\subsection{Wood Species of Rafting Withies}

The following wood species were found in use for withies: spruce or fir (Picea abies or Abies alba), poplar or willow (Populus spp. or Salix spp.), hazel (Corylus avellana), and birch (Betula pendula). Historical sources document the use of softwood for the production of withies. For example, Blau $(1917,85)$ wrote that, for the preparation of withies, young softwood trees were cut during the late autumn and were prepared for use during the early spring.

Oak, birch, beech, and hazel bushes were used only if there was not enough softwood available (Sponeck 1825, 129). In one of the most important books dealing with rafting on River Danube in Austria, hazelwood, which was used in context of withies for raft construction, is only noted once for a raft construction at the River Alm (Newekolwsky 1952, 578).

Species identification of the withies in the Hofburg displayed a considerable use of hardwood, though softwood withies were found in abundance. In total, $57 \%$ of the withies in all roof constructions were identified as spruce or fir, $26 \%$ as poplar or willow, $14 \%$ as hazel, and $4 \%$ as birch. As illustrated in Fig. 7 , this distribution differs strongly between the different wings of the Hofburg.

\subsection{Tracing Back the Origin of the Timber Rafts by Means of Typology}

To determine whether the different types of raft assembling systems could be assigned to certain areas of origin during period of construction of the wings of the Hofburg, data of six different parts of the Hofburg, each with a 


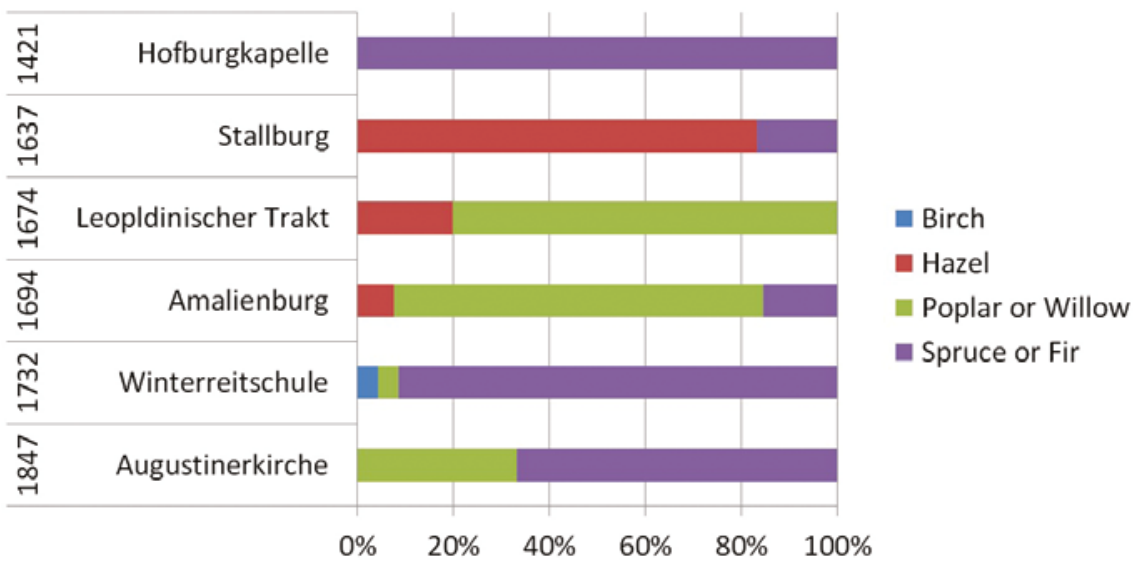

FIGURE 7 Wood species of the withies in the six parts of the Hofburg with homogenous building time.

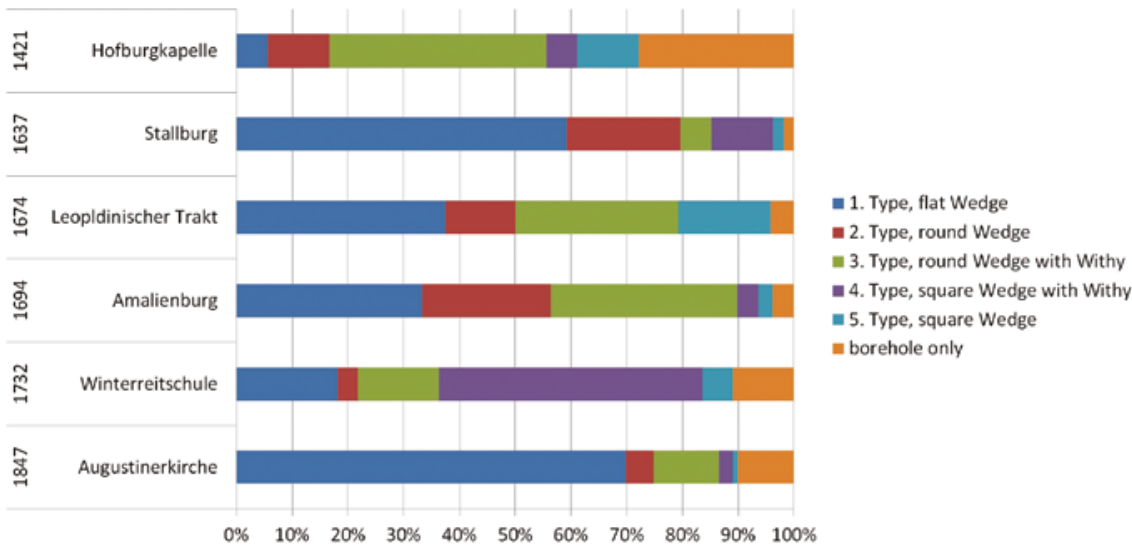

FIGURE 8 Types of rafting wedges in six parts of the Hofburg with more homogenous building time.

homogeneous building time (meaning a single building phase at a time), were analyzed in more detail (see Fig. 8). These classifications did not have an impact on the typology established, as the types of rafting wedges were not confined to single building phase, but were found in all of them.

Different factors could explain why raft assembling systems were not homogeneous in each of the various roof constructions. One reason could be a miscellaneous origin of individual logs. Neweklowsky (1952, 6o9-614) notes that rafts coming from rivers with smaller tributaries usually were attached to a bigger raft when they reached the larger tributaries or water bodies or 
were sometimes completely rebuilt once they reached River Danube. While it is tempting to see the presence of multiple wedge types as evidence that the rafts were dismantled and reassembled on the way down the rivers, the wedges also could have had different functions within a raft built in one place. According to Neweklowsky $(1952,609-614)$, some rafts went down the rivers without modification.

\subsection{Example:Amalienburg}

It is instructive to focus on Amalienburg, which was built in the late 17th century. Beech wedges without a borehole (type 1) and wedges made of various wood species with borehole were witnessed. Round wedges with and without withies were discovered (types 2 and 3, see Fig. 8). Boreholes with a diameter of $25 \mathrm{~mm}$ and withies made of poplar or willow predominated. Information in the archives of Steyr, a town in Upper Austria, proved that the town supplied wood for ceiling and roof constructions for Amalienburg. When the timber bound for Vienna was passing by Steyr, it was transported on at least two different rivers, Enns and Danube (see Fig. 9). This could be the reason for the different types of connector systems being witnessed in the Amalienburg.

The origin of wood could be determined by results from dendroprovenancing, as demonstrated by Grabner et al. (2021).

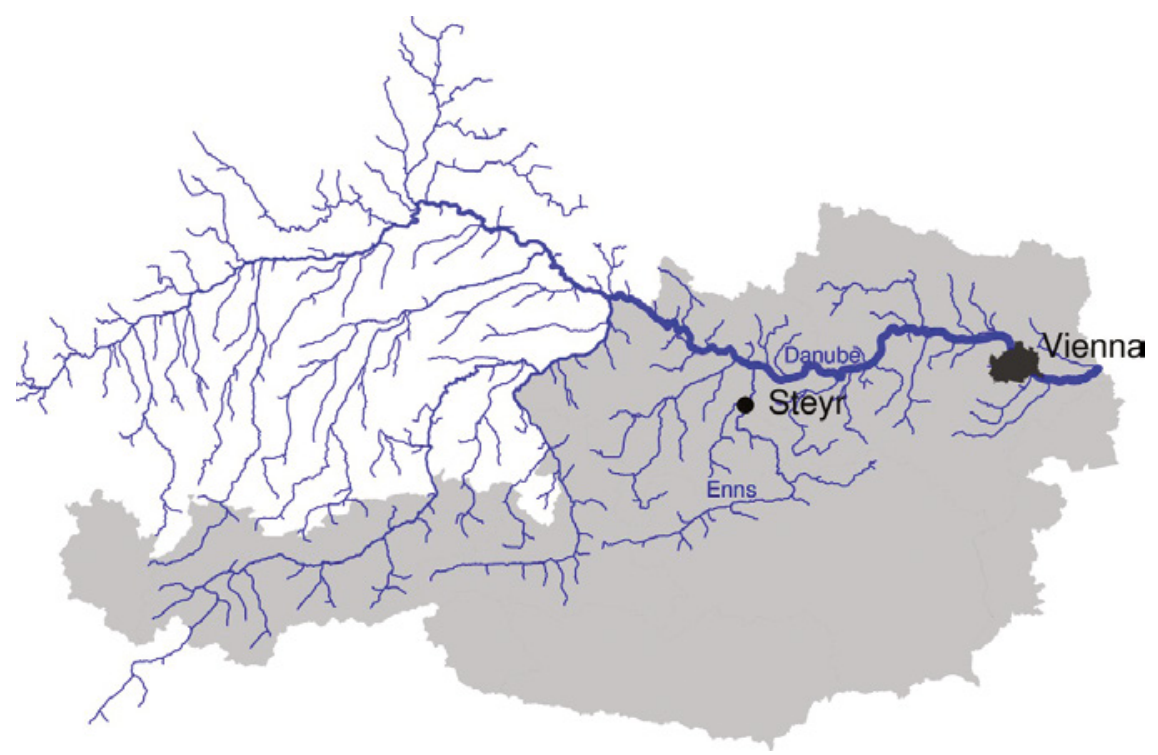

FIGURE 9 River Danube and its tributaries. 


\section{Conclusion and Outlook}

A combination of different analytical approaches of the traces of transport, dendroprovenancing, and archival analyses enabled the research team of this project to develop a better understanding of historic transport of timber. The development of a new provenancing tool based on a raft assembling typology can be of significant benefit to future studies that employ a combination of different approaches.

\section{Literature}

Blau J. 1917. Böhmerwälder Hausindustrie und Volkskunst (reprint). Morsak: 85 .

Buchinger G., Farka C. 2003. Dehio-Handbuch: Die Topographisches Denkmälerinventar-Wien I. Bezirk-Innere Stadt. Berger: 384-465.

Gayer K. 1894. Die Forstbenutzung: 372-397.

Grabner M., Karanitsch-Ackerl S., Wächter E., Bolka M. 2014. New regional eastern Austria - a basis for dendroprovenancing and dendroclimatology. Poster at EuroDendro, September 8-12, 2014, Lugo, Spain.

Grabner M., Wächter E., Karanitsch-Ackerl S., Jeitler M., Buchinger G. 2021. Log Transport in the Limestone Alps, Austria: Where Did the Timber Go? International Journal of Wood Culture 1, DOI: 10.1163/27723194-20210004.

Grosser D. 2003. Die Hölzer Mitteleuropas: ein mikrophotographischer Lehratlas: 5 o. Kessel, Remagen.

Herrenleben S.G. 1689. Sammlung Oesterreichischer Ordnungen. Codicis: 292.

Koller E. 1954. Die Holztrift Linz. Verlag des Amtes der o.ö. Landesregierung, Linz.

Neweklowsky E. 1952. Die Schiffahrt im Raume der oberen Donau. Oberösterreichischer Landesverlag: 6o9-614.

Neweklowsky E. 1959. Die Flößerei auf den alpinen Nebenflüssen der oberen Donau. Jahrbuch des Österreichischen Alpenvereins 1959: 111-138. Universitätsverlag Wagner, Innsbruck.

Sazenhofen C.-J. 198o. Handwerksfibel Flößerei München: 21-73. Staackmann, Munich. Schweingruber F. 199o. Mikroskopische Holzanatomie: 208. Flück-Wirth Verlag, Teufen. Sponeck G. 1825. Handbuch des Flosswesens: 129.

Wächter E. 2012. Dendro-Provenienz am Beispiel des Konstruktionsholzes der Wiener Hofburg. Bakkaulareatsarbeit Universität für Bodenkultur Wien, Vienna.

Wächter E., Grabner, M. 2012. Dendro-provenancing - Results from the Vienna Castle (Hofburg). Poster at the Second Workshop on Historical Wood Utilization, Egmond aan Zee, Netherlands, September 28-30.

Wiesenhofer H., Wiesenhofer F. 2015. Trift auf Erlauf. Erlauftaler Bildungskreis, Purgstall. 